\title{
Factors affecting accumulation of summer grass for winter standing feed in the high country
}

\author{
K.M. POLLOCK ${ }^{1}$, D. SCOTT and J.S. ROBERTSON ${ }^{2}$ \\ AgResearch, PO Box 60, Lincoln \\ 'Present address: Department of Plant Science, PO Box 84, Lincoln University, Canterbury \\ ${ }^{2}$ Present address: Alex MCD onald (Merchants) Ltd, Christchurch
}

\begin{abstract}
A 0.5 ha 6 -year trial compared 6 grass species $\mathrm{x} 4$ $\mathrm{N}$ fertiliser rates $\mathrm{x} 2$ times of closing for summersaved standing winter feed. The pre-winter yields averaged $3.4 \mathrm{t}$ DM/ha from November, closing with a high browntop/sweet vernal component, as compared with $1.7 \mathrm{t} \mathrm{DM} / \mathrm{ha}$ from December closings with a low browntop/sweet vernal component. Grasslands Kara cocksfoot was the highest yielding cultivar, followed by Grasslands Apanui cocksfoot, Grasslands Wana cocksfoot, Grasslands Roa tall fescue, Grasslands Nui perennial ryegrass and Grasslands Maru phalaris, with decreasing proportions of sown grass. Nitrogen fertiliser had a limited effect on prewinter yields but did have a carry-over effect into spring yields.
\end{abstract}

Keywords: Dactylis glomerata, fertiliser, Festuca arundinacea, high country, Lolium perenne, nitrogen-; Phalaris aquatica, winter Teed

\section{Introduction}

Winter feed for stock is one of the main limitations to pastoral agriculture in the South island high country. Summer-saved standing pasture is one option. A number of grasses compared for yields and winter digestibilities (Scott \& Maunsell 1986) showed that pre-winter yields were more important in determining available winter feed than the loss of digestibility or dry matter content of the standing material during the early part of the winter. Other similar trials, at Tara Hills (Douglas \& Drew 1969; Daly \& Allan 1985), showed that high amounts of standing herbage going into the winter did not deteriorate any faster than lesser masses, and that cocksfoot was likely to be the most useful grass species.

In the USA and Britain the main factors affecting the early winter yields of summer-autumn saved pastures have been the length of the accumulation period, nitrogen (N) fertiliser and autumn weather (Barker et al. 1965; Archer \& Decker 1977; Ocumpaugh \& Matches 1977; Rayburn et al. 1979). Longer accumulation periods generally gave a lower feed quality but this was usually offset by the increased herbage mass going into the winter. Benefits of $\mathrm{N}$ fertiliser are dependent on adequate temperature and moisture during the accumulation period.

Dryland pastures in the high country produce comparatively little during the summer and autumn owing to low soil moisture (Scott \& Maunsell 1981). The implication is that if grass pastures are to be saved for standing winter grazing then they may need to be closed in the late spring or early summer to create a 'feed bank' (Allan et al. 1985). The trial looks at a number of these factors in relation to grass species and cultivars.

\section{Methods}

The 0.5 ha trial was conducted at the Mt John trial site, Lake Tekapo, on a Tekapo soil on moraine topography. The site was a mosaic of hieracium (Hieracium pilosella) and browntop-dominated depleted fescue tussock grassland_before_over-drilling-grasses-with-the-rotary hoe drill in September 1984. The trial was a split-split plot design with fenced main plots of 2 summer closings x 2 replications with subplots of 6 grass cultivars within 4 nitrogen fertiliser levels. The ultimate plot size was 2 x $25 \mathrm{~m}$ drilled strips.

The six grass treatments were cocksfoot (Dactylis glomerata) cultivars of Grasslands Kara, Grasslands Apanui, Grasslands Wana, Grasslands Roa tall fescue (Festuca arundinacea), Grasslands Nui perennial ryegrass (Lolitum perenne) and Grasslands Maru phalaris (Phafaris aquatica). The four $\mathrm{N}$ fertiliser levels were; nil, $50 \mathrm{~kg} \mathrm{~N} / \mathrm{ha}$ as urea in March; $25 \mathrm{~kg} \mathrm{~N} / \mathrm{ha}$ in Sept and $50 \mathrm{~kg} \mathrm{~N} / \mathrm{ha}$ March; or $50 \mathrm{~kg} \mathrm{~N} / \mathrm{ha}$ Sept and $50 \mathrm{~kg} \mathrm{~N} /$ ha March. The two summer closings were spring grazing until closing at either mid November or mid December.

A common legume mixture of alsike, red and white clover were disc-drilled across plots and plots given a year to establish under a common $\mathrm{N}$ fertiliser rate of 50 $\mathrm{kg} \mathrm{N} / \mathrm{ha}$ at seedling emergence, $50 \mathrm{~kg} \mathrm{~N} / \mathrm{ha}$ in the first autumn (Pollock 1989), and with the differential $\mathrm{N}$ and closing treatments not applied until the second year.

Herbage mass, species composition, and live versus dead proportion in mid-May at the beginning of winter, 
were determined from a combination of calibrated capacitance probe readings, sub-sample clip quadrats and dissections, and visual rankings. Herbage mass and digestibilities in May and July in the third and fourth year were determined from clip quadrat samples. Spring herbage mass was determined from calibrated capacitance probe measurements and visual rankings of species composition.

Digestibilities were determined in vitro by neutral detergent and cellulose degradation but with the inclusion of standard reference material regressed to give estimated in vivo values.

\section{Results}

The seedling establishment of all sown grasses in the first spring was adequate (Table 1). The higher initial density of perennial ryegrass carried through to its slightly higher yield than the other sown grasses in the second and third spring. However, the relationship between the sown grasses changed once the closing treatments were imposed in the second and later years.

The combined data for the pre-winter standing feed for the second to sixth year showed significant differences related to species or cultivar, time of closing,years and the interaction between years and other treatments (Figure 1).

There were marked differences between the accumulated feed from the two closing dates, with an average of $3.4 \mathrm{DM} / \mathrm{ha}$ from the November closing and 1.7 tha from the December closing. The highest yields were from cocksfoot cultivars, with the highest from Kara, and similar yields from Apanui and Wana. The other species decreased in the order of tall fescue, perennial ryegrass and phalaris.

However, there were important differences in relation to composition, particularly the contribution by the sown grasses, and the response of the resident browntop and sweet vernal remaining between the drill strips. The significant treatment effects were the species of grass sown and time of closing but not $\mathrm{N}$ fertiliser

Table 1 Comparison of seedling density, yields and digestibility of species and cultivars.

\begin{tabular}{lcccccccc}
\hline Attribute & Kara Apanui & Wana Roa & Nui & Maru & $\begin{array}{c}\text { SE } \\
\text { diff }\end{array}$ \\
\hline $\begin{array}{l}\text { First spring } \\
\quad \text { Seedling density (no/m) }\end{array}$ & 39 & 26 & 61 & 89 & 164 & 59 & 7.5 \\
$\begin{array}{c}\text { Second spring } \\
\quad \text { Total yield (t DM/ha) }\end{array}$ & 0.90 & 0.93 & 0.89 & 0.93 & 0.97 & 0.94 & 0.06 \\
$\begin{array}{c}\text { Digestibility } \\
\text { May (\%) }\end{array}$ & 54 & 57 & 53 & 58 & 58 & 56 & 0.6 \\
$\quad$ July (\%) & 48 & 50 & 52 & 55 & 56 & 54 & 0.7 \\
\hline
\end{tabular}

Figure 1 Yield and components of pre-winter standing feed (May) in relation to species or cultivar and time of closing.

Right hand bar: sown grass (solid) and browntop/sweet vernal (cross hatch), legume (open)

Left hand bar: living material (hatch), dead (open)

Standard error for cultivar by closing date difference $=0.17$ tha

$\mathrm{K}=$ Kara cocksfoot $\quad \mathrm{R}=$ Roa tall fescue

$A=$ Apanui cocksfoot $\mathrm{N}=$ Nui perennial ryegrass

$\mathrm{W}=$ Wana cocksfoot $\quad \mathrm{M}=$ Maru phalaris

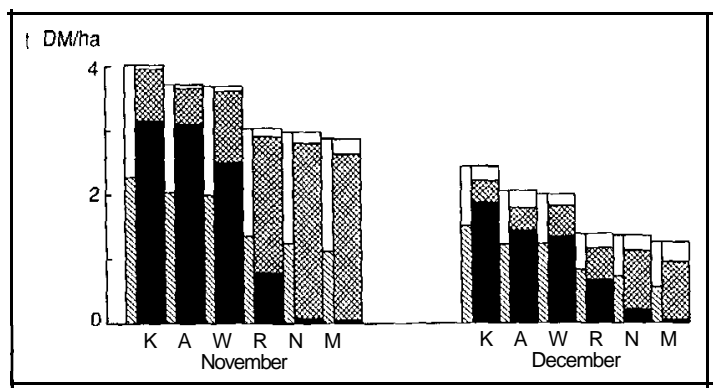

level. There was a general increase in the proportion of sown grass in the total yield, but this included a large species $\mathrm{x}$ closing time interaction. Figure 1 includes the mean composition for the fifth and sixth year. Sown cocksfoot made up more than three quarters of the total yield of its plots, tall fescue and perennial ryegrass only small proportions, and phalaris negligible proportions. Browntop and sweet vernal substituted for the latter three sown grasses. Browntop and sweet vernal also made up a higher proportion of the total in the November closed treatments. Sown legume made up only $2.6 \%$ of the pre-winter yields in the later years.

The species of sown grass was the principal significant effect for the digestibilities of the standing feed. While cocksfoots had the highest total yields they had the lowest digestibilities and decreased to a greater extent between May and July (Table 1). Because of these small differences in digestibilities the difference in yields of digestible organic matter between the sown grasses was somewhat less than indicated by the total yields.

There were significant year, year $\mathrm{x}$ closing, year $\mathrm{x} \mathrm{N}$ and year $\mathrm{x}$ species interactions, probably related to autumn rainfall. The mean pre-winter yields in 1986 were 2.2 t DM/ha, 1987 4.4, 1988 2.1, 19892.6 and $19901.5 \mathbf{t}$ $\mathrm{DM} / \mathrm{ha}$ with the corresponding total rainfall December to March being 271 
$\mathrm{mm}, 354 \mathrm{~mm}, 130 \mathrm{~mm}, 172 \mathrm{~mm}$ and $211 \mathrm{~mm}$ respectively. The interaction effects relate to a greater difference between treatments in the better growing years.

While the trend was for $\mathrm{N}$ fertiliser to increase prewinter yields, the differences were not large enough to reach statistical significance $(\mathrm{P}=0.20)$. The mean prewinter yields were respectively 2.3, 2.7, 2.6 and $2.8 \mathrm{t}$ DM/ha for the $0,50,75$ and $100 \mathrm{~kg} \mathrm{~N} / \mathrm{ha}$.

The combined data for the October spring yields for the third to sixth years showed significant effects related to species or cultivar, years, $\mathrm{N}$ and times of closing. The cocksfoots had the highest spring yield, with again the cultivar order being Kara, Apanui and Wana (Figure 2). The figure also includes the composition for the fifth year and shows again the high proportion of sown grass in the cocksfoot treatments, less in the others, and their substitution by browntop and sweet vernal. Legumes made up $7.7 \%$ of the spring yields.

Figure 2 Combined data for October spring yields for 3rd to 6th years. Sown grass (solid), resident grass (hatch), legume (open)

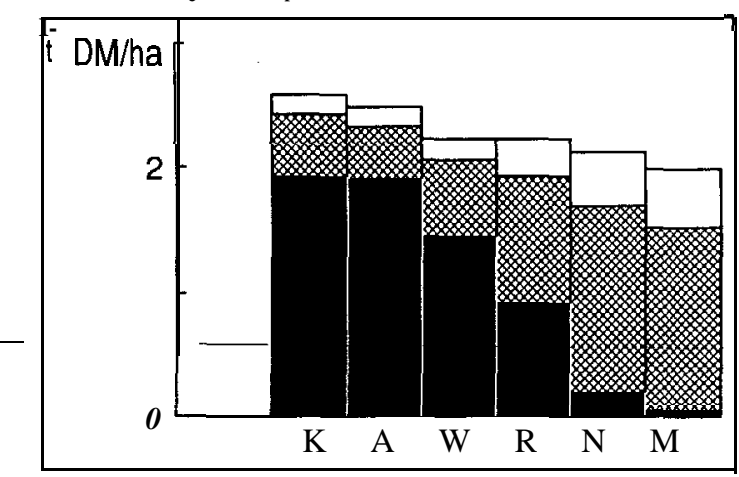

There was a significant $(\mathrm{P}=0.02)$ carry-over effect of $\mathrm{N}$ fertiliser on spring yields, these being respectively 2.1, 2.2, 2.3 and $2.4 \mathrm{t} \mathrm{DM} / \mathrm{ha}$ for the $0,50,75$ and 100 $\mathrm{kg} \mathrm{N} / \mathrm{ha}$.

\section{Discussion}

The main conclusion, as in other investigations, has been that for standing winter feed based on perennial grass species, the main requirement is to get adequate pre-winter yields before exploiting the smaller differences between species and other properties influenced by frosting duration (Eddie \& Black 1968; Douglas \& Drew 1969; Daly \& Allan 1985). Cocksfoot is the superior species in this regard because of its yield accumulation, even though its winter digestibilities are somewhat below those of other grasses.
The yields presented in Figures 1 and 2 were only for the mid spring and pre-winter after summer spelling. They do not include the main growth period of late spring/early summer. The growth rates in that period are indicated by the differences in pre-winter yields from one month's difference in closing in either November or December. They also demonstrate again that in dryland conditions, pastures for winter have to be closed by at least December to accumulate adequate pre-winter yields.

The intention of the $\mathrm{N}$ fertiliser treatments had been to boost the amount of pre-winter feed available. The results have indicated that there may be a relatively low response in the year of application but a significant carry over effect into the following spring and season. The pre-winter yields were low in some years. The response to additional $\mathrm{N}$ was $4.5 \mathrm{~kg} \mathbf{D M} / \mathrm{kg} \mathrm{N}$ for the pre-winter yields and $3.6 \mathrm{~kg} \mathrm{DM} / \mathrm{kg} \mathrm{N}$ for the spring yields, i.e., $8.1 \mathrm{~kg} \mathrm{DM} / \mathrm{kg} \mathrm{N}$, and not including the main growth period of late spring/early summer.

The implication is that $\mathrm{N}$ applications should not be seen as panic solutions for getting growth in crisis autumns, but as means of raising the mean productivity levels over a number of years. The carry-over effect of time of closing on the following spring yields demonstrates the point.

While cocksfoots were clearly the superior species and cultivars in this particular situation, both in total yield and contribution of sown grass, the results also illustrate another principle: that species like browntop and sweet vernal can respond to the changed environment of new inputs and produce to within half to two thirds of the potential of the changed environment (Scott et al. 1985). Kara was the superior cocksfoot cultivar as it had been in earlier trials (Scott \& Maunsell 1986). On this more extreme high country site, perennial ryegrass though performing well in the initial two years, did not persist.

\section{ACKNOWLEDGEMENTS}

Mr P. Nes for digestibility determinations, Mr B.L. Sutherland for technical assistance, and Ravensdown Fertiliser Ltd for fertiliser.

\section{REFERENCES}

Allan, B.E.; Lowther, W.L.; Walton, P.J. 1985. Planning, establishment and management of pastures in high country. In Burgess, R.E. \& Brock J.L. (eds) Using herbage cultivars. Grasslands research andpractice series 3: 17-21.

Archer, K.A.; Decker, A.M. 1977. Autumn accumulated tall fescue and orchard grass. 1. Growth and quality 
as influenced by nitrogen and soil temperature. Agronomy journal 69: 601-605.

Barker, H.K; Chard, J.R.A.; Hughes, W.E. 1965. A comparison of cocksfoot and tall fescue dominant swards for out-of-season production. Journal of the British Grasslands Society 20: 84-90.

Daly, M.J.; Allan, B.E. 1985. Autumn saved pasture in a high frost environment. Proceedings of the New Zealand Grassland Association 46: 135-40.

Douglas, J.A.; Drew, K.R. 1969. Value of cocksfoot for winter grazing in the tussock grassland environment. New Zealand agricultural science 4: 23-24.

Eddie, J.; Black, J.S. 1968. Herbage utilization on hill pastures. In Hill-land productivity. British Grasslands Society occasional symposium 4: 191 195.

Ocumpaugh, W.R.; Matches, A.G. 1977. Autumn-winter yield and quality of tall fescue. Agronomy journal 69: 639-643.

Pollock, K.M. 1989. Grass establishment and performance on a high country soil fertilised with nitrogen. New Zealand journal of agricultural research 32: 7-15.

Rayburn, E.B.; Blaser, R.E.; Wolf, D.D. 1979. Winter tall fescue yield and quality with different accumulation periods and $\mathrm{N}$ rates.Agronomyjournal 71: $959-963$.

Scott, D.; Maunsell, L.A. 1981. Pasture irrigation in the Mackenzie Basin. I. Species comparison. New Zealandjournal of experimental agriculture 9: 279290.

Scott, D.; Maunsell, L.A. 1986. Winter feed quality of some grasses in the high country. New Zealand journal of experimental agriculture 14: 19-24.

Scott, D.; Keoghan, J.M.; Cossens, G.G.; Maunsell, L.A.; Floate, M.J.S.; Wills, B.J.; Douglas, G. 1985. Limitations to pasture production and choice of species. In Burgess, R.E.; Brock, J.L. (eds) Using herbage cultivars. Grasslands research andpractice series 3. 